\title{
Heavy Metals Contaminated Environments and the Road Map with Phytoremediation
}

\author{
Eucharia Oluchi Nwaichi1,2*, Om Parkash Dhankher² \\ ${ }^{1}$ University of Port Harcourt, Port Harcourt, Nigeria \\ ${ }^{2}$ University of Massachusetts Amherst, Amherst, MA, USA \\ Email: "nodullm@yahoo.com
}

Received 2 November 2015; accepted 5 January 2016; published 8 January 2016

Copyright (C) 2016 by authors and Scientific Research Publishing Inc.

This work is licensed under the Creative Commons Attribution International License (CC BY). http://creativecommons.org/licenses/by/4.0/

c) (i) Open Access

\section{Abstract}

This review presents the justification of research into heavy metals and clean-up technologies with particular emphasis on phytoremediation of heavy metals contaminated soils. The generating sectors and heavy metal contaminant contributors are reviewed alongside likely types. The new paradigm by researchers in response to negative impacts of various clean-up methodologies has been discussed. This work reports limitations and prospects of phytoremediation in view of the future direction and reviewed issues with bioavaliability, mobility, and response by plants to heavy metals in their environment. It reviews various plants used in phytoremediation of heavy metals and level of success recorded by teeming researchers. Diverse options available for optimization of this relatively novel technique to enhance performance have been elaborated. Suggestions for responsible abandonment of emitting sites and facilities, safety issues and appropriate disposal and management methods for plants used in this technology have been documented.

\section{Keywords}

Phytoremediation, Heavy Metals, Soil Contamination, Biosafety, Phytotoxicity

\section{Introduction}

The quest to meet man's basic need for food, clothing and shelter has continually heightened pollution of the biosphere, especially the soil. This in response has elicited keen interest among researchers to access, remediate (in a responsible manner), monitor and build industrial capacities through reliable data generated. Of contaminants identified, Alkorka [1] has labeled heavy metals as the most dangerous substances in the environment due to their recalcitrance, unlike organic counterparts, increased mobility under changing physical and chemical

\footnotetext{
Corresponding author.
} 
conditions and persistent toxicity to biota. The addition of excess common heavy metals with various human activities like arsenic, cadmium, lead, and zinc in zinc smelting operations [2] especially with unmuffled roasting furnaces, has heightened levels of these environmental terrors. A heavy metal is any metal or metalloid of environmental concern and has been defined giving great contributions from Dufus [3], Hawkes [4] and Blake [5], based on their density $\left(>3.5 \mathrm{~g} / \mathrm{cm}^{3}\right.$ to $\left.7 \mathrm{~g} / \mathrm{cm}^{3}\right)$, atomic weight ( $>22.98 \mathrm{for} \mathrm{Na}$ ), atomic number ( $>20$ to 92$)$, toxicity (toxic) or periodic table position (all the metals in Groups 3 to 16 that are in periods 4 and greater). There is no widely agreed definition of a heavy metal. Activities such as mining [6], smelting [7], oil exploration and expolitation [8], manufacturing facilities [9], illicit refuse disposal [10], electroplating, fertilisers [11] and paints manufacture, wood treatment, vehicular emissions especially tetraethyl lead [12], sewage sludge application to agricultural soils [13], firearm training giving off lead from lead azide or lead styphnate used in firearms [14], etc., have been implicated in heavy metals contamination of soil. Heavy metals enter plant, animal and human tissues via air inhalation, food, water and contact. Arsenic, which is low in nature although toxic [15] can become elevated as a by-product of $\mathrm{Zn}, \mathrm{Pb}$ and $\mathrm{Cu}$ smelting activities [2]. Thus, arsenic is classified in EPA's Group A as a human carcinogen and is regulated as such. Carey et al. [16] describe the binding of AsIII (inorganic specie of As) to Cys residues as one that disrupts protein structure and function, thus affecting many key metabolic processes in the cell, such as oxidative phosphorylation, glutathione production, ATP synthesis, fatty acid metabolism, and gluconeogenetic pathway. According to Lenntech [17], International Agency for Research on Cancer (IARC) has listed cobalt and cobalt compounds within Group 2B (agents which are possibly carcinogenic to humans). Cadmium and lead have got listed as EPA class $B_{1}$ metals and are very toxic [15] at high concentrations. Alkorta [1] describes Cd as highly mobile in plant-soil systems, although with less evident toxicity, and is described as by-product of $\mathrm{Zn}$ and $\mathrm{Pb}$ mining and smelting. Lead is more complex to remove especially when introduced to soil matrix but they can be mobilized into the solution phase by changing the soil $\mathrm{pH}$, temperature, redox potential, and soil organic matter composition [18]. Zinc, though not classified as mutagenic or carcinogenic [15], is toxic at high concentrations and constitutes the most mobile heavy metal because it is present as soluble compounds at neutral and acidic $\mathrm{pH}$ values [19]. People who live near hazardous waste sites, nuclear power plants and mines, work in the phosphate industry, eat produce from contaminated soil, or drink water from a uranium waste disposal point may experience a higher uranium exposure than other people. Although, root vegetables (such as radishes) may contain higher than usual concentrations of uranium (as heavy metal and as a radiological hazard) as plants absorbing uranium through their roots and store it there, they are removed when the vegetables are washed [15].

Lenntech [15] also reported higher-than-usual exposure for artists that use them for glasswork, despite the fact that uranium glazes are banned. While uranium itself is not particularly dangerous, some of its decay products do pose a threat, especially radon, which can build up in confined spaces such as basements [15]. However, Mclay [20] reported toxic effect on the living cells as processes of carbohydrates metabolism are inhibited by the inhibition of enzyme systems (associated with hexokinase at the sites of ATP surface-building through magnesium-hexokinase mechanism), and suggests this could account for why many people are gaining so much weight in the last couple of years. Early studies on the biological effects of uranium showed that uranium salts given by mouth presented a hazard as a mild poison causing death.

Detrimental effects of heavy metals can be viewed from their interference to the proper functioning of vital cellular components, such as structural proteins, enzymes, and nucleic acids, when they bind to them, although it may be symptomatic or not depending on type and dose. Important manisfestations has been reported as shown in Table 1 to underscore the importance of assessment, management and prevention of heavy metals contamination. This review evaluates the state of heavy metals contamination and clean-up vis-a-vis phytoremediation to examine prospects ahead.

\section{Overview of Plants Used for Phytoremediation and Recorded Degree of Success}

\subsection{Justification and Limitation of Technique}

Heavy metals have impacted on the ecosystem through discharges as effluents, dust and/or leachate. Although many metals are essential, all metals are toxic at elevated concentrations, because they form free radicals thereby causing oxidative stress and can replace essential metals in pigments or enzymes disrupting their function [21]. In a bid to clean contaminated soils, different agencies, companies and researchers have employed leaving the contamination as it is and restricting the utilization of the land (Stegmann, 2001), complete or partial encap- 
Table 1. Varying exposure conditions with common heavy metals in humans.

\begin{tabular}{|c|c|c|c|}
\hline Element & Acute exposure & Chronic exposure & Condition \\
\hline Cadmium & Pneumonitis (lung inflammation) & $\begin{array}{c}\text { Lung cancer } \\
\text { Osteomalacia (softening of bones) } \\
\text { Proteinuria (excess protein in urine; } \\
\text { possible kidney damage) }\end{array}$ & $\begin{array}{l}\text { Cadmium } \\
\text { poisoning }\end{array}$ \\
\hline Mercury & $\begin{array}{l}\text { Diarrhea } \\
\text { Fever } \\
\text { Vomiting }\end{array}$ & $\begin{array}{c}\text { Stomatitis (inflammation of gums and mouth) } \\
\text { Nausea } \\
\text { Nephrotic syndrome (nonspecific kidney disorder) } \\
\text { Neurasthenia (neurotic disorder) } \\
\text { Parageusia (metallic taste) } \\
\text { Pink Disease } \\
\text { (pain and pink discoloration of hands and feet) tremor }\end{array}$ & $\begin{array}{l}\text { Mercury } \\
\text { poisoning }\end{array}$ \\
\hline Lead & $\begin{array}{c}\text { Encephalopathy (brain dysfunction) } \\
\text { Nausea } \\
\text { Vomiting }\end{array}$ & $\begin{array}{c}\text { Anemia } \\
\text { Encephalopathy } \\
\text { Foot drop/wrist drop (palsy) } \\
\text { Nephropathy (kidney disease) }\end{array}$ & $\begin{array}{c}\text { Lead } \\
\text { poisoning }\end{array}$ \\
\hline Chromium & $\begin{array}{l}\text { Gastrointestinal hemorrhage (bleeding) } \\
\text { Hemolysis (red blood cell destruction) } \\
\text { Acute renal failure }\end{array}$ & $\begin{array}{l}\text { Pulmonary fibrosis (lung scarring) } \\
\text { Lung cancer }\end{array}$ & $\begin{array}{l}\text { Chromium } \\
\text { toxicity }\end{array}$ \\
\hline Arsenic & $\begin{array}{c}\text { Nausea } \\
\text { Vomiting } \\
\text { Diarrhea } \\
\text { Encephalopathy } \\
\text { Multi-organ effects } \\
\text { Arrhythmia } \\
\text { Painful neuropathy }\end{array}$ & $\begin{array}{c}\text { Diabetes } \\
\text { Hypopigmentation/Hyperkeratosis } \\
\text { Cancer }\end{array}$ & $\begin{array}{l}\text { Arsenic } \\
\text { poisoning }\end{array}$ \\
\hline Zinc & & $\begin{array}{l}\text { Acute gastrointestinal and respiratory damages } \\
\text { and acute heart, brain and kidney damages }\end{array}$ & Zinc toxicity \\
\hline Nickel & Respiratory, skin and heart aches & $\begin{array}{l}\text { Total defects in infants, cardiovascular defects } \\
\text { and defects of the musculoskeletal system }\end{array}$ & Nickel toxicity \\
\hline Copper & $\begin{array}{l}\text { Flu-like condition known as } \\
\text { metal fever, vomiting, diarrhea, } \\
\text { stomach cramps, and nausea }\end{array}$ & $\begin{array}{l}\text { Wilson's disease, characterized by a hepatic cirrhosis, } \\
\text { brain damage, demyelization, renal disease, } \\
\text { and copper deposition in the cornea, and even death }\end{array}$ & $\begin{array}{c}\text { Copper } \\
\text { poisoning }\end{array}$ \\
\hline Selenium & $\begin{array}{l}\text { Decreased synthesis of thyroid } \\
\text { hormones and metabolism of growth } \\
\text { hormone and insulin-like growth factor-1 }\end{array}$ & Neurotoxicity, nail and hair loss and dermatitis & $\begin{array}{l}\text { Selenium } \\
\text { poisoning }\end{array}$ \\
\hline Colbalt & $\begin{array}{l}\text { Vomiting and nausea, } \\
\text { vision problems }\end{array}$ & $\begin{array}{l}\text { Lung effects, such as asthma and pneumonia, } \\
\text { heart problems, thyroid damage }\end{array}$ & $\begin{array}{c}\text { Cobalt } \\
\text { Poisoning }\end{array}$ \\
\hline Uranium & Mild aches & $\begin{array}{l}\text { Kidney disease, cancer with enriched uranium, } \\
\text { inhibit the processes carbohydrates metabolism } \\
\text { by the inhibition of enzyme systems, } \\
\text { childhood and breast cancer in high prone zones }\end{array}$ & $\begin{array}{l}\text { Uranium } \\
\text { Poisoning }\end{array}$ \\
\hline
\end{tabular}

Afal \& Wiener [69]; Chashschina et al. [70]; Lenntech [17]; Vinceti et al. [71].

sulation (isolation and containment) of the contaminated site, dig-and-dump, burying of contaminated soil, dilution of contaminated soil with clean soil, electrokinetics [22] for low permeable soils, use of chemicals (oxidizing agents, acids and solvents) [22] and dispersants (in situ or ex situ), and thermal treatments (ex situ), potentially endangering biota [23] and causing deterioration of groundwater quality. Conventional methods of remediation have been estimated at $\$ 10$ to 1000 per cubic meter besides its environmentally destructiveness [24] while phytoextraction costs are estimated to be as low as $\$ 0.05$ per cubic meter [25]. To achieve efficiency, and costeffectiveness, biological methodologies with environmental compatibility, have evolved with bioremediation (with bacteria, fungi, algae, plankton, and protozoa) serving well in clean-up of organics [13] as well as stabilization of heavy metals but not their breakdown. An emerging technology, phytoremediation uses plants and their associated microbes for the removal of pollutants from the environment or to reduce their toxicity [26]. Several advantages ranging from aesthetics purposes, cost-effectiveness, less environmental disturbance, less 
technical—know how on implementation, have been associated with phytoremediation of heavy metal polluted sites. Raskin and Ensley [27] reported the sheilding advantage, as ground cover of plants, preventing the blowing of contaminated dust around the neighborhood apart from the widely acclaimed metal hyperaccumulating property of the plants. Despite identified limitations as enumerated by Pilon-Smits [28], which include handling concerns of phytoaccumulators after clean-up, limited applicability of this method to a heavily contaminated soil, given long time required for cleaning up the contaminated site, limitation of technique to bioavailable fraction of pollutant in the soil, phytoremediation has enjoyed wide studies among researchers. In situ design has presented lowered cost and impact on the ecosystem. Overall, appropriate remediation technique for a heavy metal contaminated site is time consuming, site specific and tricky and therefore needs full understanding of available options, nature of metal, acessibility to site and available resources. Among identified phytoremediation classifications, phytoextraction, phytostabilization, phytovolatilization (for $\mathrm{Hg}$ and Se) [28], and rhizofiltration are most implicated in the remediation of heavy metals contaminated environments. Different plants, given their local advantages may fit a case and not the other in phytoremediation of heavy metals in soils because interest heavy metals are present in soil in different fractions. They can therefore be dissolved in soil solution (Figure 1), attached to exchange sites on inorganic soil constituents, adsorbed to inorganic soil constituent, attached to insoluble organic matter, or as precipitates of pure or mixed solids, based on the properties of the individual metals.

\subsection{Brief Classifications of Phytoremediation}

\subsubsection{Phytoextraction}

This is a technique that concentrates contaminants in the harvestable parts of plants capable of phytoaccumulating high biomass production. It has been reported to preserve structure and fertility of such soils as less disturbance is required [29]. Hyperaccumulators are plants that contain greater than or up to $0.1 \%$ i.e. more than (1000 $\mathrm{mg} / \mathrm{g}$ ) of copper, cadmium, chromium, lead, nickel cobalt or $1 \%(>10,000 \mathrm{mg} / \mathrm{g})$ of zinc or manganese in the dry matter and their cropping may be repeated until desired result is acheived. For cadmium and other rare metals, it is $>0.01 \%$ by dry weight [30]. Their phytoextraction however, may be limited to 3 feet and 10 feet [25] from surface for soil and ground water heavy metal contamination respectively. Areas of high metal contamination may signal potential hyperaccumulator species. Baker and Brooks [30] reported prevalence of various metal hyperaccumulation in the Brassicaceae family as 87 species (of about 400 from 22 families) from 11 genera has been documented. Brooks et al. [31] posits that if phytoextraction could be combined with biomass generation and its commercial utilization as an energy source, then it can be turned into profit making operation and the remaining ash can be used as bio-ore and this forms the basic principle of phytomining.

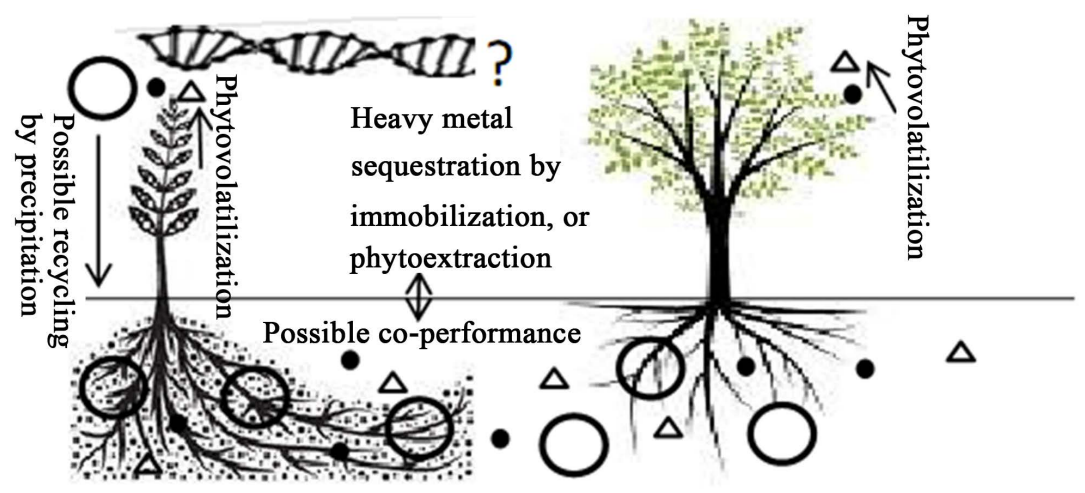

Figure 1. Mechanism and current status of phytoremediation of heavy metals in contaminated soils metals are sequestered in soil by immobilization, transformation and uptake into plant tissues. Horizontal line shows harvestable plant part that is mostly ashed. Metals like Se and Hg have been shown to be successfully volatilized in non toxic form. However, possibility of recycling by precipitation and leaf drop is feared. Co-plant rhizosperic interactions have been shown to modify paerformance of species at metal uptake as conditions in the shared rhizospheres may influence metal bioavailability to neighboring plants. Screening of plants for multi-metal hyperaccumators is ongoing considering competition by certain heavy metals such as $\mathrm{Cu}$ and $\mathrm{Zn}, \mathrm{Ni}$ and $\mathrm{Cd}$ for same membrane protein transporters. Figure also shows the future of this technique with genetic engineering in root, leaf, biomass, tolerance, accumulation potentials of identified species. Note different heavy metal contaminants (in circles and triangles) undergoing either immobilization or mineralization via natural plant exudation or supplementation with synthetic chelators for possible tissue uptake. 


\subsubsection{Phytostabilization}

This is a complexation technique that dwindles contaminant mobility and bioavailability in soils, sludges and sediments thereby limiting biomagnification via erosion and leaching. This localised contaminants however may require some level of monitoring. Locally available materials like crushed mussel shell may be explored as reported by Garrido-Rodríguez et al. [32] who observed diminished copper desorption and mobilization rates in copper enriched vineyard and mine samples even at low $\mathrm{pH}$ of 3.

\subsubsection{Phytovolatilization (for $\mathrm{Hg}$ and Se)}

This technique involves the venting of contaminants or their metabolites via the leaves (Figure 1) to the atmosphere. Pilon-Smits [28] enlisted some inorganics (Hg and Se) capable of existing in volatile forms and volatile organic carbons as susceptible to this technique. Meagher et al. [33] reported absorption of $\mathrm{Hg}(\mathrm{II})$ and volatilization of $\mathrm{Hg}(0)$ by $N$. tabacum and an engineered model A. thaliana (with a gene for mercuric reductase). Similarly transformed yellow poplar (Liriodendron tulipifera) plantlets showed resistance to, and grew well in $\mathrm{Hg}$ contaminated regimes. Successes have also been recorded with tritium removal [34] with phytovolatilization. Utmost care however needs to be taken to exclude possibility of recycling by precipitation (Figure 1) when considering a contaminant metabolic route thereof.

\subsubsection{Rhizofiltration}

This is the in situ or ex situ adsorption, absorption, and precipitation of inorganic and organic contaminants from mild contaminated environments, especially liquid discharges, using plant (terrestrial and aquatic) roots. This is most ideal for metal ( $\mathrm{Ni}, \mathrm{U}, \mathrm{Cr}, \mathrm{Cd}, \mathrm{Zn}, \mathrm{Pb}$ and $\mathrm{Cu}$ ) contaminants that are basically retained in the root section [29] [35] [36]. Raskin and Ensley [27] suggested a preferential use of terrestrial over aquatic plants since they have a fibrous and much longer root system, increasing the amount of root area.

\subsubsection{Phytotransformation}

This is the total or partial degradation of organic contaminants by breakdown or transformation into simpler forms that are incorporated into plant tissues. This breakdown may be by plant enzyme (usually dehalogenases, oxygenases and reductases) [37] or rhizodegration (breakdown or organic contaminants usually as fuel or solvent, by rhizopheric microbial acitivities.

\subsubsection{Useful Ratios for Interpretation}

To further qualify performance, some ratios like concentration ratio (the ratio of the metal concentration in the shoot of the plant to that in the soil based on wet weight) has been used to indicate presence or absence of accumulation in uptake studies. Similarly, bioconcentration factor also known as bioaccumulation factor or enrichment coefficient [9] is often used and is computed as the ratio of a given metal concentration in the plant tissues (dry weight) [38] at harvest to the concentration of the metal in the concerned environmental component. Larger values are taken to describe better phytoaccumulation capability. A phytoextraction coefficient of 1.7 was reported for Brassica juncea and it has been found that a lead concentration of $500 \mathrm{mg} / \mathrm{l}$ is not phytotoxic to Brassica species [21]. Another ratio, translocation factor has been computed as the ratio of the metal concentration in root tissues to their conterparts in shoot tissues [39]. Calculation of the time required for cleaning up the soil with plant can also be determined using the amount of metal accumulated in the harvestable parts of the plant (shoot), and the bioavailable metal present in the soil.

\subsubsection{Recorded Success}

Phytoremediation of heavy metal contaminated soil has attracted scientists of diverse origin, culture, race and disciplines because the environment is involved. The heightened interest is not restricted to researchers but also to industries and most importantly the government nationally and internationally springing up relevant study grants among others, as the global thirst for cheaper, simpler and more eco-friendly technologies rockets. Exposure responses, removal efficiencies and phytoextraction and accumulation possiblities have been explored by several researchers. It is known that to enhance metal solubility, plants either excrete organic ligands or lower the soil $\mathrm{pH}$ in the rhizosphere. To mimicksuch natural enhanced metal solubility via exudation or $\mathrm{pH}$ reduction. Romkens et al. [40] reported success with administration of synthetic chelates such as ethylenediaminetetraacetic acid (EDTA), nitrilotriacetic acid, pyridine-2-6-dicarboxylic acid, citrate, nitric acid, malate, histidine [41], 
hydrochloric acid and fluorosilicic acid at phytoremediation studies. Many chelates have been tested and the order of effectiveness in increasing $\mathrm{Pb}$ desorption from the soil was EDTA > Hydroxyethylethylene-diaminetriacetic acid (HEDTA) > Diethylenetriaminepentaacetic acid (DTPA) > Ethylenediamine di(o-hyroxyphenylacetic acid) EDDHA [42]. The addition of lime or organic matter has been reported to lower heavy metal metal solubility [28] at near phytotoxic levels.

Also, Mathew [7] reported reduced \% bioavailability with increased contaminant load for As (28.8, 2.1 and $\left.0.26 \mathrm{mg} \cdot \mathrm{kg}^{-1}\right)$ and $\mathrm{Cd}\left(26.2,15.2\right.$ and $\left.9 \mathrm{mg} \cdot \mathrm{kg}^{-1}\right)$ for low, medium and heavy contaminated smelting site respectively. Observed trend was reversed with zinc while no particular order was established by the researcher for $\mathrm{Pb}$. This pattern manifested in higher shoot uptake level for $\mathrm{Zn}$ in corn as reported Mathew [7]. Although only the bioavalable fraction of heavy metal in the soil is subject to phytoremediation, some of the tightly bound heavy metals can be become bioavailable with exhaustion of the bioavailable fraction. Arsenic was higher in roots than in leaves for corn [7] but higher in leaves with Chinese Brake ferns [43]. Corn gave a better heavy metal uptake when compared to sunflower although both gave significant successes as observed by Mathew [7] and Spirochova et al. [44].

Mechanism of heavy metal accumulation (Figure 1) is being studied. Cosio et al. [45] investigated the mechanisms of $\mathrm{Zn}$ and $\mathrm{Cd}$ accumulation in different plant species (T. caerulescens "Ganges" and A. halleri) through ion compartmentation by measuring their short term ${ }^{109} \mathrm{Cd}$ and ${ }^{65} \mathrm{Zn}$ uptake in mesophyll protoplast and suggested a regulation mechanism in place. Response of plant parts to exposure is under wide research. In that vein, Nwaichi et al. [46] and Whiting et al. [47] found increased root biomass and root length in favour of hydrocarbon and heavy metal phytotoxicity in $V$. subterranean and $T$. carerulescens respectively. Co-plant rhizosperic interactions have been shown to modify performance of species at metal uptake. In their study, Gove et al. [48] observed up to 2.4 factor increase for Cd uptake in $H$. vulgare plants when grown alongside (with no barrier) of $T$. caerulescens. The case however, was reversed (decrease) for Zn uptake in H. vulgare. This may have arisen due to alerations in conditions in the shared rhizospheres and which may have influenced metal bioavailability to neighboring plants. Similar observations were made by Wenzel et al. [49] using S. alfredii and Z. mays. Current methods for recovery of heavy metals from plant biomass of hyperaccumulators are unclear given increasing cost with energy used for gasification. Further, pollution could result if metals are volatile giving ashing (of metal-rich biomass) and recovery methods, where disposal as harzardous waste is not followed. Competition by certain heavy metals such as $\mathrm{Cu}$ and $\mathrm{Zn}, \mathrm{Ni}$ and $\mathrm{Cd}$ for same membrane protein transporters was reported by Clarkson and Luttge [50]. This could have a serious implication in the choice of plants for the cleanup in co-contamination systems.

Inorganic and organic agents, including EDTA, citric acid, elemental sulfur or ammonium sulfate [51] [52], and urea have been applied to soils to improve phytoextraction potentials of diffent plant species. These act as chelating material in addition to natural plant exudates. The importance of the activities of rhizosphere-associated microbes (such as several strains of bacillus and pseudomonas) at degradation of organic pollutants has been proven helpful in the B. juncea phytoextraction of the Cd [41]. Molecularly, enhancement of expression of protein transporters into the root and shoot and enzymes that could modify and conjugate metals as well as enhanced level of root, xylem and phloem chelators (NA, GSH, acids) have been reported by Dhanker et al. [53]. Possible upregulation of degrading enzymes from roots has a great potential for the secretion of compounds that stimulate microbial density or activity as in rhizodegradation [53]. Genes encoding plant arsenate reductases for example have been isolated and characterized from Arabidopsis [54] and many other species including rice, Holcus lanatus, and P. Vittata. Co-expression of both $\gamma$-ECS and PCS in Arabidopsis gave a greater effect on As accumulation and tolerance than over-expression of either gene alone [55] - this firmed up preferrential successes with combined approach. Trangenic processes will therefore offer a lot to the field of phytoremediation in terms of relevant novel gene introduction and/ or modification of existing types.

In all, most of the Species used successfully in phtoremediation include Corn and Sunflower [7] for $\mathrm{Pb}$ $\left(25,008 \mathrm{mg} \cdot \mathrm{kg}^{-1}\right)$, Zn $\left(94,420 \mathrm{mg} \cdot \mathrm{kg}^{-1}\right)$, As (1658 mg $\left.\cdot \mathrm{kg}^{-1}\right)$ and Cd $\left(1281 \mathrm{mg} \cdot \mathrm{kg}^{-1}\right)$; Tossa jute (Corchorus olitorius) for As and $\mathrm{Cr}$ [56]; Chinese brake fern [57] for As and not Zn; Indian mustard (Brassica juncea) in soils up to $200 \mathrm{mg} \cdot \mathrm{kg}^{-1}$ [58], willow clones (Salix), alpine penny-cress (Thlaspi caerulescens) up to $390 \mathrm{mg} \cdot \mathrm{kg}^{-1}$ [59], sunflower (Helianthus annus) and corn (Zea mays) (up to $90 \mathrm{mg} \cdot \mathrm{kg}^{-1}$ [44] for Cd; Brassica juncea up to 500 $\mathrm{mg} \cdot \mathrm{kg}^{-1}$ and $1500 \mathrm{mg} \cdot \mathrm{kg}^{-1}$ [7] Helianthus annus and Zea mays up to $16,000 \mathrm{mg} \cdot \mathrm{kg}^{-1}$ [44], Piptatherum miliaceum (Smilo grass) up to $1550 \mathrm{mg} \cdot \mathrm{kg}^{-1}$ [60], Thlaspi praecox up to $67,940 \mathrm{mg} \cdot \mathrm{kg}^{-1}$ [61], Hemidesmus indicus up to $65 \%$ of $10,000 \mathrm{mg} \cdot \mathrm{kg}^{-1}$ [62] for $\mathrm{Pb}$; H. annus up to $350 \mathrm{ppb}$ for uranium (95\% reduction to $5 \mathrm{ppb}$ in $24 \mathrm{~h}$ ) 
[63], Piptatherum miliaceum (Smilo grass) up to $600 \mathrm{mg} \cdot \mathrm{kg}^{-1}$ [60], Pteris vitatta (a fern) up to $14,500 \mathrm{mg} \cdot \mathrm{kg}^{-1}$ for As without signs of toxicity [44], A. serpyllifolium for up to $\mathrm{Cr}$ (283 mg/kg), Cu (264 mg/kg), Pb (1433 $\mathrm{mg} / \mathrm{kg}$ ) and Zn (377 mg/kg) [64], Helianthus annus and Zea mays up to 75,000 mg. $\mathrm{kg}^{-1}$ [44]) and Thlaspi caerulescens up to $3259 \mathrm{mg} \cdot \mathrm{kg}^{-1}$ [65] and $26,000 \mathrm{mg} \cdot \mathrm{kg}^{-1}$ for $\mathrm{Zn}$ and up to $22 \%$ of soil exchangeable Cd from contaminated site [43] [66] [67] found 95\% of As localised in the harvestable portion of fern, with higher amount in older fronds, while Salt [41] observed the reverse situation in Indian Mustard for As. Similar pattern of higher accumulation on older leaves was observed in Typha domingensis by Hegazy et al. [9] in industrial wastewater remediation. Linear correlation between shoot concentrations and soil concentrations of heavy metals could be interpreted as confirmatory analysis for phytoremediation of metal using such specie [61].

\section{Prospects of Phytoremediation of Heavy Metal Contaminated Soils}

Phytoaccumulators could be subjected to metal recovery as a decontamination approach after compaction in a responsible manner and clean biomass can support agricultural management practices. Induced phytoextraction or chelate assisted phytoextraction is a way to go, to release most metals and improve phytoetraction of heavy metals. This will require a more comprehensive comparative studies of available chelators for scaled and wholistic performance. Molecular biology (with streamlined strategies for monitoring different stages of genetic manipulation) could be employed to improve required traits such as dense rooting system, high growth rate, disease resistance, selectivity to metals, high resistance to toxicity, improved biomass production, enhanced accumulator genes, etc. to enhance patronage of technique. Molecular identification of metal specific transporter genes for toxic heavy metal species are most important for those serving extra position as plant nutrient so as to avert starvation while toxic species are extracted. Broader anatomical and physiological studies of screened and identified plants for phytoremediation could open up a new area for genetic engineers in this field. Invasive species however, may not fit in these genetic manipulations as spread may be uncontrolled. Furthermore, more field trials should be done with screened species as behavioural differences in hydroponic conditions, pots and real world may suggest potential differences.

Synergistic toxic effects of multiple heavy metal contamination may require improved variety. For example, Islam et al. [56] reported that high level $\left(100 \mathrm{mg} \cdot \mathrm{kg}^{-1}\right)$ As plus $\mathrm{Cr}$ caused a further decreased plant growth and chlorophyll content, increased MDA and $\mathrm{H}_{2} \mathrm{O}_{2}$ contents as well as antioxidative enzymes activities significantly $(P \leq 0.05)$ and less severe inhibition of plant growth and oxidative damage was observed in O-795 (Cr-tolerant jute) than in O-9897 (Cr-sensitive jute) indicating variety O-795 had more efficient defense system to mitigate heavy metal induced oxidative stress. Some plants (such as Sesuvium portulacastrum L.) however posses the molecular and physiological flexibility [68] to deal with such parched sites. Also chelating agents like synthetic ethylenediamine tetra acetic acid (EDTA) was applied to $\mathrm{Pb}$ contaminated soil (total soil $\mathrm{Pb} 2500 \mathrm{mg} \cdot \mathrm{kg}^{-1}$ ) and this increased the amount of bioavailable lead in the soil and caused a greater accumulation in plants (Zea mays (corn) and Pisun sativum (pea)) from less than $500 \mathrm{mg} \cdot \mathrm{kg}^{-1}$ to more than $10,000 \mathrm{mg} \cdot \mathrm{kg}^{-1}$ [42]. This can therefore be leveraged upon.

Most researchers have made choices of their plants species based on literature, climatic conditions of study areas, specie availability and density, growth and harvest edges [19], biomass yield and tolerance [10] [28], etc. Biotechnology techniques however is currently used to develop plants with even better characteristics for phytoremeditaion such as ability to accumulate multiple metals. However, molecular mechanisms of heavy metal detoxification and tolerance in identified plants needs a deeper understanding.

Selection of high biomass weeds (non-edible, disease resistant and tolerant plants) to restrict the biomagnification of heavy metals into the food chain may advance the viability of phytoremediation (especially of phytoextraction) and may have implications in renewable energy and biodiversity preservation.

\section{Conclusion}

Heavy metals can accumulate in organisms as they are hard to metabolize. Researchers over the last ten years have globally patronised by phytoremediation studies to tackcle heavy metal removal from contaminated environments although with a load of concerns over biomass management and the pace of the technique. This environmentally friendly and relatively cheap process is fast emerging as a viable alternative to various conventional remediation methods. In a developing country like Nigeria, where most identified sources of contamination are in the boom, in a bid to meet the need of its teeming population, phytoremediation will be a good fit. Since soil 
clean-up entails return of soil to a state where it can perform its ecological functions including establishment of biota communities, it supports prior to disturbance, assessment of soil community shifts and their physiological profiles should be done to complement physical and chemical data on abandonment of site. Government and relevant agencies should go beyond paper at ensuring compliance to set regularly reviewed standards to protect and reclaim our soils and rendering measurable support to researchers in this area, while creating awareness. A review of the status of phytoremediation as a technology is timely to equip researchers and policy makers with gaps, successes and potentials embedded in this novel technology in managing the heinous environmental plaque of heavy metal contamination.

\section{Acknowledgements}

Dr. Eucharia Oluchi Nwaichi is grateful to UNESCO LO'real International Fellowships FWIS 2013 for various overseas exposure in the current field. She is also thankful to Prof. Joseph Ajienka the Vice Chancellor, University of Port Harcourt, Nigeria, for his support during various training and studies abroad.

\section{References}

[1] Alkorta, I., Hernandez-Allica, J., Becerril, J.M., Amezaga, I., Albizu, I. and Garbisu, C. (2004) Recent Findings on the Phytoremediation of Soils Contaminated with Environmentally Toxic Heavy Metals and Metalloids Such as Zinc, Cadmium, Lead, and Arsenic. Reviews in Environmental Science and Biotechnology, 3, 71-90. http://dx.doi.org/10.1023/B:RESB.0000040059.70899.3d

[2] USEPA (1995) Zinc Smelting. http://www.epa.gov/ttn/chief/ap42/ch12/final/c12s07.pdf. Retrieved 01/17/2015

[3] Duffus, J.H. (2002) Heavy Metal—A Meaningless Term? Pure and Applied Chemistry, 74, 793-807. http://dx.doi.org/10.1351/pac200274050793

[4] Hawkes, S.J. (1997) What Is a Heavy Metal? Journal of Chemical Education, 74, 1374. http://dx.doi.org/10.1021/ed074p1374

[5] Blake, J. (1884) On the Connection between Physiological Action and Chemical Constitution. The Journal of Physiology, 5, 36-44. http://dx.doi.org/10.1113/jphysiol.1884.sp000148

[6] U.S. Environmental Protection Agency (1984) Summary Report: Remedial Response at Hazardous Waste Site”. EPA-540/2-84-002a, Washington DC.

[7] Mathew, A.M. (2005) Phytoremediation of Heavy Metal Contaminated Soil. MSc Thesis. Oklahoma State University, 5-101.

[8] Nwaichi, E.O., Onyeike, E.N. and Wegwu, M.O. (2010) Comparison of Chicken Manure and UREA Fertilizers as Potential Soil Amendments for Enhanced Phytoextraction of Heavy Metals. Biorem, 14, 180-188. http://dx.doi.org/10.1080/10889868.2010.514873

[9] Hegazy, A.K., Abdel-Ghani, N.T. and El-Chaghaby, G.A. (2011) Phytoremediation of Industrial Wastewater Potentiality by Typha Domingensis. International Journal of Environmental Science and Technology, 8, 639-648. http://dx.doi.org/10.1007/BF03326249

[10] Nwaichi, E.O., Osuji, L.C. and Onyeike, E.N. (2011) Evaluation and Decontamination of Crude Oil-Polluted Soils Using Centrosema Pubescen Benth and Amendment-Support Options. International Journal of Phytoremediation, 13, 373-382. http://dx.doi.org/10.1080/15226514.2010.495144

[11] McGrath, S.P., Zhao, F.J. and Lombi, E. (2001) Plant and Rhizosphere Process Involved in Phytoremediation of MetalContaminated Soils. Plant Soil, 232, 207-214. http://dx.doi.org/10.1023/A:1010358708525

[12] Wright, D.A. and Welbourn, P. (2002) Environmental Toxicology. Cambridge University Press, Cambridge. http://dx.doi.org/10.1017/CBO9780511805998

[13] Ghosh, M. and Singh, S.P. (2005) A Review on Phytoremediation of Heavy Metals and Utilization of It's by Products. Asian Journal on Energy \& Environment, 6, 214-231.

[14] Houlton, S. (2014) Boom! Chemistry World, 11, 48-51.

[15] Evangelou, V.P. (1998) Environmental Soil and Water Chemistry Principles and Applications. Iowa State University, Iowa john Wiley and Sons, Inc., New York.

[16] Carey, A.M., Scheckel, K.G., Lombi, E., Newville, M., Choi, Y., et al. (2010) Grain Unloading of Arsenic Species in Rice. Plant Physiology, 152, 309-319. http://dx.doi.org/10.1104/pp.109.146126

[17] Lenntech (2015) Health Effects. http://www.lenntech.com/periodic/elements/

[18] Ettler, V., Vanek, A., Mihaljevic, M. and Bezdicka, P. (2005) Contrasting Lead Speciation in Forest and Tilled Soils 
Heavily Polluted by Lead Metallurgy. Chemosphere, 58, 1449-1459.

http://dx.doi.org/10.1016/j.chemosphere.2004.09.084

[19] McIntyre, T. (2003) Phytoremediation of Heavy Metals from Soils. Advances in Biochemical Engineering/ Biotechnology, 78, 97-123. http://dx.doi.org/10.1007/3-540-45991-X_4

[20] Mclay (2006) http://www.magneticclay.com/uranium_article.php

[21] Henry, J.R. (2000) In an Overview of Phytoremediation of Lead and Mercury. NNEMS Report, Washington DC, 3-9.

[22] Mulligan, C.N., Yong, R.N. and Gibbs, B.F. (2001) Remediation Technologies for Metal Contaminated Soils and Groundwater. Engineering Geology, 60, 193-207. http://dx.doi.org/10.1016/S0013-7952(00)00101-0

[23] Nwaichi, E.O., Frac, M., Peters, D.E. and Akpomiemie, B.O. (2014) Conditioners and Significance in t-RFLP Profile of the Assemblage of Prokaryotic Microorganisms in a Niger Deltaic Crude Oil Polluted Soil. African Journal of Biotechnology, 13, 4220-4225. http://dx.doi.org/10.5897/AJB2014.13886

[24] Aboulroos, S.A., Helal, M.I.D. and Kamel, M.M. (2006) Remediation of Pb and Cd Polluted Soils Using in Situ Immobilization and Phytoextraction Techniques. Soil and Sediment Contamination, 15, 199-215. http://dx.doi.org/10.1080/15320380500506362

[25] Cunningham, S.D., Shann, J.R., Crowley, D. and Anderson, T.A. (1997) Phytoremediation of Soil and Water Contaminants. American Chemical Society, Washington DC.

[26] Clemente, R., Walker, D.J. and Bernal, M.P. (2005) Uptake of Heavy Metals and as by Brassica juncea Grown in a Contaminated Soil in Aznalcollar (Spain): The Effect of Soil Amendments. Environmental Pollution, 138, 378-411. http://dx.doi.org/10.1016/j.envpol.2005.02.019

[27] Raskin, I. and Ensley, B.D. (2000) Phytoremediation of Toxic Metals: Using Plants to Clean up the Environment. John Wiley Publishers, New York.

[28] Pilon-Smits, E. (2005) Phytoremediation. Annual Review of Plant Biology, 56, 15-39. http://dx.doi.org/10.1146/annurev.arplant.56.032604.144214

[29] United States Environmental Protection Agency Reports (2000) Introduction to Phytoremediation. EPA600/R-99/107.

[30] Baker, A.J.M. and Brooks, R.R. (1989) Terrestrial Higher Plants Which Hyperaccumulate Metalic Elements. A Review of Their Distribution, Ecology and Phytochemistry. Biorecovery, 1, 81-126.

[31] Brooks, R.R., Chambers, M.F., Nicks, L.J. and Robinson, B.H. (1998) Phytomining. Trends in Plant and Science, 1, 359-362. http://dx.doi.org/10.1016/S1360-1385(98)01283-7

[32] Garrido-Rodríguez, B., Fernández-Calviño, D., Nóvoa Muñoz, J.C., Arias-Estévez, M., Díaz-Raviña, M., ÁlvarezRodríguez, E., Fernández-Sanjurjo, M.J. and Núñez-Delgado, A. (2013) pH-Dependent Copper Release in Acid Soils Treated with Crushed Mussel Shell. International Journal of Environmental Science and Technology, 10, 983-994. http://dx.doi.org/10.1007/s13762-013-0201-8

[33] Meagher, R.B., Rugh, C.L., Kandasamy, M.K., Gragson, G. and Wang, N.J. (2000) Engineered Phytoremediation of Mercury Pollution in Soil and Water Using Bacterial Genes. In: Terry, N. and Bañuelos, G., Eds., Phytoremediation of Contaminated Soil and Water, Lewis Publishers, Boca Raton, 201-219.

[34] Dushenkov, D. (2003) Trends in Phytoremediation of Radionuclides. Plant and Soil, 249, 167-175. http://dx.doi.org/10.1023/A:1022527207359

[35] Chaudhry, T.M., Hayes, W.J., Khan, A.G. and Khoo, C.S. (1998) Phytoremediation-Focusing on Accumulator Plants That Remediate Metal-Contaminated Soils. American Journal Experts, 4, 37-51.

[36] Dushenkov, S., Vasudev, D., Kapolnik, Y., Gleba, D., Fleisher, D., Ting, K.C. and Ensley, B. (1997) Removal of Uranium from Water Using Terrestrial Plants. Environmental Science and Technology, 31, 3468-3476. http://dx.doi.org/10.1021/es9702201

[37] Black, H. (1995) Absorbing Possibilities: Phytoremediation. Environmental Health Perspectives, 103, 1106-1108. http://dx.doi.org/10.1289/ehp.951031106

[38] Nwaichi, E.O. and Onyeike, E.N. (2010) Cu Tolerance and Accumulation by Centrosema Pubescen Benth and Mucuna Pruriens Var Pruriens. Archives of Applied Science Research, 2, 238-247.

[39] Sutapa, B. and Bhattacharyya, A.K. (2008) Heavy Metal Accumulation in Wheat Plant Grown in Soil Amended with Industrial Sludge. Chemosphere, 70, 1264-1272. http://dx.doi.org/10.1016/j.chemosphere.2007.07.062

[40] Römkens, P., Bouwman, L. and Japenga, D.J.C. (2002) Potentials and Drawbacks of Chelate-Enhanced Phytoremediation of Soils. Environmental Pollution, 116, 109-121. http://dx.doi.org/10.1016/S0269-7491(01)00150-6

[41] Salt, D.E., Blaylock, M., Kumar, P.B.A.N., Dushenkov, V., Ensley, B.D., Chet, L. and Raskin, L. (1995) Phytoremediation: A Novel Strategy for the Removal of Toxic Metals from the Environment Using Plants. Nature Biotechnology, 13, 468-474. http://dx.doi.org/10.1038/nbt0595-468 
[42] Huang, J.W., Chen, J., Berti, W.R. and Cunningham, S.D. (1997) Phytoremediation of Lead Contaminated Soils-Role of Synthetic Chelates in Lead Phytoextraction. Environmental Science \& Technology, 31, 800-806. http://dx.doi.org/10.1021/es9604828

[43] Zhang, Z.Z., Li, M.Y., Chen, W., Zhu, S.Z., Liu, N.N. and Zhu, L.Y. (2010) Immobilization of Lead and Cadmium from Aqueous Solution and Contaminated Sediment Using Nano-Hydroxyapatite. Environmental Pollution, 158, 514519. http://dx.doi.org/10.1016/j.envpol.2009.08.024

[44] Spirochova, I.K., Puncocharova, J., Kafka, Z., Kubal, M., Soudek, P. and Vanek, T. (2003) Accumulation of Heavy Metals by in Vitro Cultures of Plants. Water, Air, \& Soil Pollution, 3, 269-276. http://dx.doi.org/10.1023/A:1023933902452

[45] Cosio, C., Martinoia, E. and Keller, C. (2004) Hyperaccumulaton of Cadium and Zinc in Thlaspi caerulescens and Arabidopsis hallri at Leaf Cellular Level. Plant Physiology, 134, 716-725. http://dx.doi.org/10.1104/pp.103.031948

[46] Nwaichi, E.O., Onyeike, E.N., Wegwu, M.O. (2010) Characterization and Safety Evaluation of the Impact of Hydrocarbon Contaminants on Ecological Receptors. Bulletin of Environmental Contamination and Toxicology, 85, 199-204. http://dx.doi.org/10.1007/s00128-010-0062-5

[47] Whiting, N.S., Leake, R.J., McGrath, P.S. and Baker, M.J.A. (2000) Positive Response to Zn and CD by Roots of the Zn and Cd Hyperaccumulator Thlaspi caerulescens. New Phytologist, 145, 199-210. http://dx.doi.org/10.1046/j.1469-8137.2000.00570.x

[48] Gove, B., Hutchinson, J.J., Young, S.D. and McGrath, S.P. (2002) Uptake of Metals by Plants Sharing a Rhizosphere with the Hyperaccumulator Thlaspi caerulescens. International Journal of Phytoremediation, 4, 267-281. http://dx.doi.org/10.1080/15226510208500087

[49] Wenzel, W.W., Bunkowski, M., Puschenreiter, M. and Horak, O. (2002) Rhizosphere Characteristics of Indigenously Growing Nickel Hyperaccumulator and Excluder Plants on Serpentine Soil. Environmental Pollution, 123, 131-138. http://dx.doi.org/10.1016/S0269-7491(02)00341-X

[50] Clarkson, D.T. and Luttge, U. (1989) Mineral Nutrition: Divalent Cations, Transport and Compartmentation. Progress in Botany, 51, 93-112. http://dx.doi.org/10.1007/978-3-642-75154-7 7

[51] Cunningham, S.C. and Berti, W.R. (2000) Phytoextraction and Phytostabilization: Technical, Economic, and Regulatory Considerations of the Soil-Lead Issue. In: Terry, N. and Banuelos, G., Eds., Phytoremediation of Contaminated Soil and Water, Lewis Publishers, Boca Raton, 359-376.

[52] Schmidt, U. (2003) Enhancing Phytoremediation: The Effect of Chemical Soil Manipulation on Mobility, Plant Accumulation, and Leaching of Heavy Metals. Journal of Environmental Quality, 32, 1939-1954. http://dx.doi.org/10.2134/jeq2003.1939

[53] Dhankher, O.P., Elizabeth, A.H., Pilon-Smits, E., Meagher, R.B. and Doty, S. (2012) Biotechnological Approaches for Phytoremediation. In: Altman, A. and Hasegawa, P.M., Eds., Plant Biotechnology and Agriculture, Elsevier Publications, San Diego, 302-323. http://dx.doi.org/10.1016/b978-0-12-381466-1.00020-1

[54] Dhankher, O.P., Rosen, B.P., McKinney, E.C. and Meagher, R.B. (2006) Enhanced Arsenic Uptake in Arabidopsis Plants by Suppressing Endogenous Arsenate Reductase AtACR2 Gene. Proceedings of the National Academy of Sciences of the United States of America, 103, 5413-5418. http://dx.doi.org/10.1073/pnas.0509770102

[55] Guo, O., Dai, X., Xu, W. and Ma, M. (2008) Overexpressing GSH1 and AsPCS1 Simultaneously Increases the Tolerance and Accumulation of Cadmium and Arsenic in Arabidopsis thaliana. Chemosphere, 72, 1020-1026. http://dx.doi.org/10.1016/j.chemosphere.2008.04.018

[56] Islam, M.K., Khanam, M.S., Lee, S.Y., Alam, I. and Huh, M.R. (2014) The Interaction of Arsenic (As) and Chromium (Cr) Influences Growth and Antioxidant Status in Tossa Jute (Corchorus litorius). Plant Omics Journal, 7, 499-509.

[57] Caille, N., Swanwick, S., Zhao, F.J. and McGrath, S.P. (2004) Arsenic Hyperaccumulation by Pteris vittata from Arsenic Contaminated Soils and the Effect of Liming and Phosphate Fertilisation. Environmental Pollution, 132, 113120. http://dx.doi.org/10.1016/j.envpol.2004.03.018

[58] Jiang, X.J., Luo, Y.M., Zhao, Q.G., Baker, A.J.M., Christie, P. and Wong, M.H. (2003) Soil Cd Availability to Indian Mustard and Environmental Risk Following EDTA Addition to Cd-Contaminated Soil. Chemosphere, 50, 813-818. http://dx.doi.org/10.1016/S0045-6535(02)00224-2

[59] Wu, Q., Xu, Z., Meng, Q., Gerard, E. and Morel, J. (2004) Characterization of Cadmium Desorption in Soils and Its Relationship Toplant Uptake and Cadmium Leaching. Plant \& Soil, 258, 217-226.

[60] Garcia, G., Faz, A. and Cunha, M. (2004) Performance of Piptatherum miliaceum (Smilo Grass) in Edaphic Pb and Zn Phytoremediation over a Short Growth Period. International Biodeterioration and Biodegradation, 54, $245-250$. http://dx.doi.org/10.1016/j.ibiod.2004.06.004

[61] Mikus, K.V., Drobne, D. and Regvar, M. (2005) Zn, Cd, and Pb Accumulation and Arbuscular Mycorrhizal Colonization of Pennycress Thlaspi praecox Wulf (Brassicaceae) from the Vicinity of Lead Mine and Smelter in Slovenia. 
Environmental Pollution, 133, 233-242. http://dx.doi.org/10.1016/j.envpol.2004.06.021

[62] Sekhar, K.C., Kamala, C.T., Chary, N.S., Balaram, V. and Garcia, G. (2005) Potential of Hemidesmus indicus for Phytoextraction of Lead from Industrially Contaminated Soils. Chemosphere, 58, 507-514. http://dx.doi.org/10.1016/j.chemosphere.2004.09.022

[63] Schnoor, J.L. (1997) Phytoremediation. Department of Civil and Engineering, University of Lowa, Iowa, 62.

[64] Ma, L.Q., Komar, K.M., Tu, C., Zhang, W., Cai, Y. and Kenelley, E.D. (2001) Bioremediation: A Fern That Hyperaccumulates Arsenic. Nature, 409, 579. http://dx.doi.org/10.1038/35054664

[65] Kidd, P.S. and Monterroso, C. (2005) Metal Extraction by Alyssum serpyllifolium ssp. lusitanicum on Mine-Spoil Soils from Spain. Science of The Total Environment, 336, 1-11. http://dx.doi.org/10.1016/j.scitotenv.2004.06.003

[66] Brown, S.L., Chaney, R.L., Angle, J.S. and Baker, A.J.M. (1995) Zinc and Cadmium Uptake by Hyperaccumulator Thlaspi caerulescens Grown in Nutrient Solution. Soil Science Society of America Journal, 59, 125-133. http://dx.doi.org/10.2136/sssaj1995.03615995005900010020x

[67] Gerard, E., Echevarria, G., Sterckeman, T. and Morel, J.L.P. (2000) Availability of Cd to Three Plant Species Varying in Accumulation Pattern. Journal of Environmental Quality, 29, 1117-1123. http://dx.doi.org/10.2134/jeq2000.00472425002900040012x

[68] Lokhande, V.H., Gor, B.K., Desai, N.S., Nikam, T.D. and Suprasanna, P. (2013) Sesuvium portulacastrum, a Plant for Drought, Salt Stress, Sand Fixation, Food and Phytoremediation. A Review. Agronomy for Sustainable Development, 33, 329-348. http://dx.doi.org/10.1007/s13593-012-0113-x

[69] Afal, A. and Wiener, S.W. (2014) Metal Toxicity. Medscape.org, retrieveed 21 December 2014.

[70] Chashschina, V.P., Artuninaa, G.P. and Norseth, T. (1994) Congenital Defects, Abortion and Other Health Effects in Nickel Refinery Workers. Science of the Total Environment, 148, 287-291. http://dx.doi.org/10.1016/0048-9697(94)90405-7

[71] Vinceti, M., Wei, E.T., Malagoli, C., Bergomi, M. and Vivoli, G. (2001) Adverse Health Effects of Selenium in Humans. Reviews on Environmental Health, 16, 233-251. 